\title{
Utilization of Bottom Ash and Sawdust Waste as a Substitute for Fine Aggregate in Concrete Mix
}

\author{
Kosim Kosim ${ }^{1, *}$ Zainuddin Zainuddin $^{1}$ Raja Marpaung $^{1}$ Darma Prabudi ${ }^{1}$ \\ ${ }^{I}$ State Polytechnic of Sriwijaya \\ ${ }^{*}$ Corresponding author. Email: kosimmt@gmail.com
}

\begin{abstract}
Concrete is a split mixture, sand, cement, water, and additives. The concrete to be designed is made of a mixture of cement with bottom ash + sawdust, split, sand, and water. The purpose of this study was to determine the effect of using bottom ash + sawdust and the ratio between bottom ash + sawdust and fine aggregate. In this study using variations of 0\%BA+SK: 100\%AH; 5\%BA+SK: 95\%AH; $10 \% \mathrm{BA}+\mathrm{SK}: 90 \% \mathrm{AH} ; 15 \% \mathrm{BA}+\mathrm{SK}: 85 \% \mathrm{AH} ; 20 \% \mathrm{BA}+\mathrm{SK}: 80 \% \mathrm{AH}$; $25 \% \mathrm{BA}+\mathrm{SK}: 75 \% \mathrm{AH}$. The results of testing the compressive strength of concrete at the age of 28 days for $0 \% \mathrm{BA}+\mathrm{SK}$ : 100\%AH; 5\%BA+SK: 95\%AH; 10\%BA+SK: $90 \% \mathrm{AH}$ and 15\%BA+SK: $85 \% \mathrm{AH}$ obtained $262.52 \mathrm{~kg} / \mathrm{cm} 2 ; 253.63$ $\mathrm{kg} / \mathrm{cm} 2 ; 242.67 \mathrm{~kg} / \mathrm{cm} 2$; and $235.11 \mathrm{~kg} / \mathrm{cm} 2$ meet the requirements for concrete quality of $225 \mathrm{~kg} / \mathrm{cm} 2$. For a mixture of $20 \% \mathrm{BA}+\mathrm{SK}: 80 \% \mathrm{AH}, 25 \% \mathrm{BA}+\mathrm{SK}: 75 \% \mathrm{AH}$ at the age of 28 days obtained $203.70 \mathrm{~kg} / \mathrm{cm} 2$ and $197.93 \mathrm{~kg} / \mathrm{cm} 2$ and does not meet the concrete quality requirements of $225 \mathrm{~kg} / \mathrm{cm} 2$. Concrete mixture using $15 \% \mathrm{BA}+\mathrm{SK}$ : $85 \% \mathrm{AH}$ is the best concrete mixture, and the concrete compressive strength is $235.11 \mathrm{~kg} / \mathrm{cm} 2$. The more the use of bottom ash and sawdust into the concrete mixture, the compressive strength of the concrete will decrease.
\end{abstract}

Keywords: Bottom Ash, Sawdust, Concrete Compressive Strength

\section{PRELIMINARY}

\subsection{Background}

Coal production in Indonesia continues to increase every year. The use of coal as an energy source in Steam Power Plants (PLTU) is most in demand because of the abundant availability of coal in Indonesia and also influenced by relatively lower operating costs compared to other energy sources. Tekmira (2010), states that the process of converting coal into energy at the PLTU produces ash from combustion of 8-10\% consisting of fly ash and bottom ash. Bottom ash is the ash produced during the combustion of coal that settles. If the coal ash is not managed properly, it will cause environmental pollution and disturb the surrounding community.

Infrastructure development in Indonesia has increased starting from roads, bridges, buildings. This of course requires more and more construction materials. One of the most important construction materials is concrete. Concrete is an artificial material consisting of several mixtures of cement, water, coarse aggregate, fine aggregate, and other additives if needed.
In Indonesia, the utilization of bottom ash as a construction material has not been maximized. Bottom ash has pozzolanic properties that are suitable when used in the manufacture of concrete. Concrete that uses bottom ash as a mixture of fine aggregate is more stable and has resistance to chloride ion penetration than concrete without bottom ash (Sing and Siddique, 2015).

With this sand material, it will become thinner over time, for that it is necessary to make concrete with a mixture of bottom ash and wood sawdust and fine aggregate.

Based on the above background, the problem that will be discussed in this research is how much influence the use of bottom ash and sawdust has in making concrete with variations in the ratio between bottom ash waste and sawdust and fine aggregate: $0 \% \mathrm{BA}+\mathrm{SK}: 100 \% \mathrm{AH} ; 5 \%$ BA+SK: 95\% AH; $10 \%$ BA+SK: $90 \%$ AH; $15 \%$ BA+SK: $85 \%$ AH; $20 \%$ BA+SK: $80 \%$ AH; $25 \%$ BA+SK: $75 \% \mathrm{AH}$

\subsection{Concrete}

Concrete is a mixture consisting of natural aggregates, such as gravel, sand, crushed stone, with 
Portland cement as a binder, then Portland cement with water to form a binding paste of aggregate grains into a solid mass that is insoluble in water. The above ingredients are mixed until homogeneous with a certain ratio, to produce a plastic condition so that it is easy to work with, and if necessary, an admixture can be added. The heat of hydration produced by cement and water through a chemical reaction that occurs between them, forms a bond between the aggregate grains, both coarse and fine aggregates, with the cement and water, resulting in a hardening and an increase in strength. The addition of concrete strength will occur continuously and reach maximum strength when the concrete reaches the age of \pm 28 days

\subsection{Bottom Ash}

The use of coal as an energy source to replace fuel, on the one hand is very profitable, but on the other hand can cause problems. The main problem with the use of coal is coal ash, which is a by-product of burning coal. Several coal uses will produce coal ash of about $2-10 \%$. Currently, the management of coal ash waste is only limited to stockpiling in the factory area (ash disposal). Coal ash is part of the coal combustion residue in the form of amorphous fine particles. The ash is an inorganic material formed from changes in mineral matter due to the combustion process. The process of burning coal in a steam generator unit (boiler) will form two types of ash, namely fly ash, and bottom ash. The composition of coal ash consists of $10-20 \%$ base ash and $80-90 \%$ fly ash. Fly ash is captured with an electric precipitator before being discharged into the air through the chimney. Many studies have been conducted to review the effect of added materials on improving the quality of concrete. (Damayanti and Rochman, 2006).

\subsection{Compressive Strength of Concrete}

The main strength of concrete is its compressive strength. The value of the compressive strength of concrete increases with increasing age and at the age of 28 days, the concrete reaches its maximum strength. 28 days old. The measurement of the compressive strength of concrete refers to the standard SK SNI M14-1989-F (SNI 03-1974-1990). The loading on the compressive strength test is in the form of a load that works continuously distributed through the center of gravity. The formula for calculating the compressive strength of concrete, namely:

$$
f^{\prime} c=\frac{P}{A}
$$

Information:

$f^{\prime} \mathrm{c}=$ compressive strength of concrete $\left(\mathrm{kg} / \mathrm{cm}^{2}\right)$

$\mathrm{P}=\operatorname{load}(\mathrm{kg})$

A $=$ cross-sectional area $\left(\mathrm{cm}^{2}\right)$

\section{RESEARCH METHODS}

\subsection{The scope of research}

This research was conducted in the city of Palembang, with the material source of Baturaja cement, coarse aggregate from the Lahat area, fine aggregate from the Tanjung Raja area, coal waste in the form of bottom ash and wood sawdust from the rest of the manufacture of frames and doors.

\subsection{Data collection technique}

The data obtained from the results of testing the quality of the materials to be used include cement, coarse aggregate, fine aggregate, water, bottom ash, and wood sawdust. Material quality testing refers to the Indonesian National Standard (SNI). If the quality of the material to be used meets the requirements, then proceed with making 72 pieces of concrete cube specimens. Then proceed with testing the compressive strength of concrete. The results of the compressive strength test of concrete will be evaluated and compared to the compressive strength of normal concrete, namely concrete made without bottom ash and wood sawdust.

\subsection{Data analysis}

The analysis of the results will determine the quality of the concrete mixture after using Baturaja cement material, coarse aggregate from the Lahat area, fine aggregate from the Tanjung Raja area, wood sawdust from the rest of the manufacture of frames and doors, and bottom ash, which is the residue of burning coal, will be loaded in table and made a graph of the test results of the compressive strength of concrete.

\subsection{Research methods}

This study uses the following standards: Indonesian National Standard (SNI), ASTM (American Society for Testing Material) Standards, AASHTO (American Association of State Highway and Transportation) standards.

\section{RESULTS AND DISCUSSION}

\subsection{Material Quality Test}

\subsubsection{Coarse Aggregate Sieve Analysis Test}

The fine aggregate that will be used will be mixed with other materials, for that it is necessary to know what the specific gravity value is, this is important because it will be used when calculating the design of the concrete mix.

The results of the sieve analysis of coarse aggregate are shown in Table 1 and illustrated in Figure 1. 
Table 1. Test Results of Coarse Aggregate Sieve Analysis

\begin{tabular}{|c|c|c|c|c|}
\hline $\begin{array}{c}\text { Sieve } \\
\text { Number } \\
(\mathrm{mm})\end{array}$ & \multicolumn{3}{|c|}{ Shortcuts Styles } & $\begin{array}{c}\text { Cumulative } \\
\text { Pass } \\
(\%)\end{array}$ \\
\cline { 2 - 5 } & (grams) & $(\%)$ & $\begin{array}{c}\text { Cumulative } \\
(\%)\end{array}$ & \\
\hline 38,0 & 0 & 0 & 0 & 100 \\
\hline 19,0 & 632,9 & 63,29 & 63,29 & 36,71 \\
\hline 9,5 & 191,7 & 19,17 & 82,46 & 17,54 \\
\hline 4,75 & 136,3 & 13,63 & 96,09 & 3,91 \\
\hline 2,36 & 21,8 & 2,18 & 98,27 & 1,73 \\
\hline 1,18 & 5,6 & 0,56 & 98,83 & 1,17 \\
\hline 0,60 & 3,9 & 0,39 & 99,22 & 0,78 \\
\hline 0,30 & 3,1 & 0,31 & 99,53 & 0,47 \\
\hline 0,150 & 1,8 & 0,18 & 99,71 & 0,29 \\
\hline 0,075 & 1,5 & 0,15 & 99,86 & 0,14 \\
\hline Pan & 1,4 & 0,14 & - & - \\
\hline \multicolumn{7}{|c|}{ Total Number } & 863,33 & \\
\hline
\end{tabular}

Grain Fineness Modulus $=\%$ Cumulative Hold / 100

$$
=863,33 / 100=8,633
$$

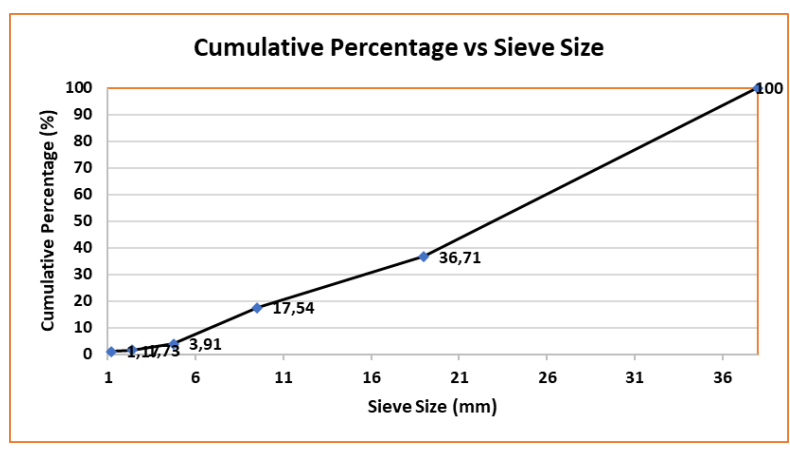

Figure 1 Gradation of Coarse Aggregate

\subsubsection{Fine Aggregate Sieve Analysis Test Results}

The results of the sieve analysis of fine aggregate are shown in Table 2 and illustrated in Figure 2.

Table 2. Test Results of Fine Aggregate Sieve Analysis

\begin{tabular}{|c|c|c|c|c|}
\hline $\begin{array}{c}\text { Sieve } \\
\text { Number } \\
(\mathrm{mm})\end{array}$ & \multicolumn{3}{|c|}{ Shortcuts Styles } & $\begin{array}{c}\text { Cumulative } \\
\text { Pass } \\
(\%)\end{array}$ \\
\cline { 2 - 5 } & (grams) & $(\%)$ & $\begin{array}{c}\text { Cumulative } \\
(\%)\end{array}$ & \\
\hline 4,75 & 5,6 & 0,56 & 0,56 & 99,44 \\
\hline 2,36 & 21,1 & 2,11 & 2,67 & 97,33 \\
\hline 1,18 & 24,2 & 2,42 & 5,09 & 94,91 \\
\hline 0,60 & 210,1 & 21,01 & 26,1 & 73,9 \\
\hline 0,30 & 559,1 & 55,91 & 82,01 & 17,99 \\
\hline 0,150 & 163,3 & 16,33 & 98,34 & 1,66 \\
\hline 0,075 & 15,2 & 1,52 & 99,86 & 0,14 \\
\hline Pan & 1,4 & 0,14 & - & - \\
\hline \multicolumn{7}{|c|}{ Total Number } & 314,63 & \\
\hline
\end{tabular}

Grain Fineness Modulus $=\%$ Cumulative Hold $/ 100$

$$
=314,63 / 100=3,146
$$

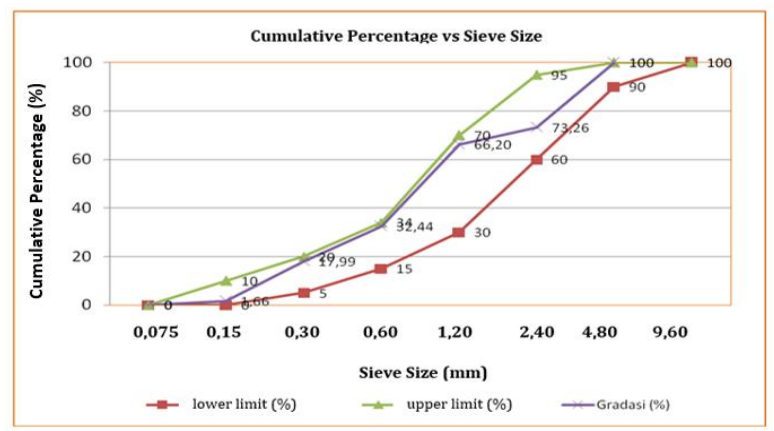

Figure 2 Gradation of Coarse Aggregate

The results of the fine aggregate sieve analysis show that the fine aggregate gradation is in zone 2, meaning that the sand used is of the ideal grain size.

\subsubsection{Testing Of Fine Specific Gravity And Saturated Surface Dry And Absorption Of Fine Aggregate}

The fine aggregate that will be used will be mixed with other materials, for that it is necessary to know what the specific gravity value is, this is important because it will be used when calculating the mix design so that it can be seen how much fine aggregate needs for other concrete constituents.

The results of testing for specific gravity and fine aggregate absorption, as shown in Table 3 .

Table 3. Test Results of Specific Gravity and Absorption of Fine Aggregate

\begin{tabular}{|l|c|}
\hline \multicolumn{1}{|c|}{ Test Items } & Weight (gr) \\
\hline $\begin{array}{l}\text { Saturated Surface Dry Sample } \\
\text { Weight }\end{array}$ & 500 \\
\hline Oven Dry Sample Weight & 467 \\
\hline $\begin{array}{l}\text { The weight of the pycnometer } \\
\text { filled with water }\end{array}$ & 1266,9 \\
\hline Picno weight + SSD sample + water & 1563,3 \\
\hline Bulk specific gravity & 2,294 \\
\hline Saturated surface density & 2,456 \\
\hline Absorption & 7,066 \\
\hline
\end{tabular}

\subsubsection{Testing Of Bulk Specific Gravity And Saturated Surface Dry And Absorption Coarse} Aggregate

The specific gravity of coarse aggregate ranges from 2.0 to 2.6, the greater the specific gravity of the aggregate, the better the concrete produced. The results of testing the specific gravity and absorption of coarse aggregate, as shown in Table 4. 
Table 4. Test Results of Specific Gravity and Absorption of Fine Aggregate

\begin{tabular}{|l|c|}
\hline \multicolumn{1}{|c|}{ Test Items } & Weight (gr) \\
\hline $\begin{array}{l}\text { Saturated Surface Dry Sample } \\
\text { Weight }\end{array}$ & 781,20 \\
\hline Oven Dry Sample Weight & 473,40 \\
\hline $\begin{array}{l}\text { The weight of the pycnometer } \\
\text { filled with water }\end{array}$ & 895,10 \\
\hline Picno weight + SSD sample + water & 1191,3 \\
\hline Bulk specific gravity & 2,595 \\
\hline Saturated surface density & 2,624 \\
\hline Absorption & 1,098 \\
\hline
\end{tabular}

\subsection{Material Quality Test}

Comparison of the compressive strength of concrete without using bottom ash and sawdust against the compressive strength of normal concrete, as shown in Figure 3.

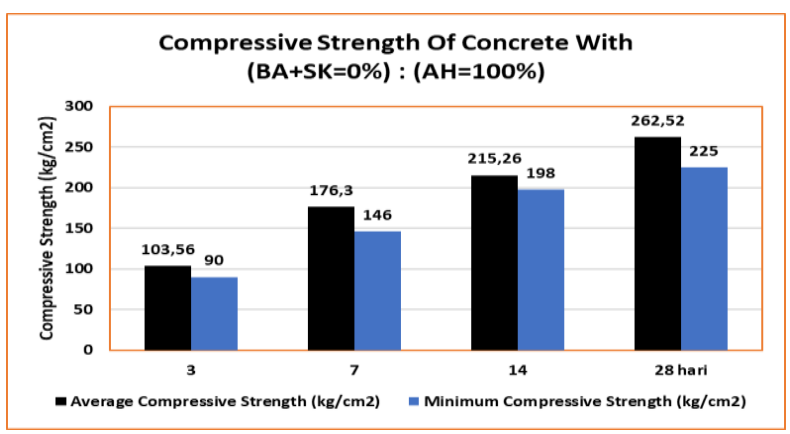

Figure 3 Comparison of Compressive Strength of Concrete at Age 3, 7, 14 and 28 days

From the results of testing the compressive strength of concrete, the compressive strength of concrete is $262.52 \mathrm{~kg} / \mathrm{cm}^{2}$, meeting the planned compressive strength of $225 \mathrm{~kg} / \mathrm{cm}^{2}$ at the age of 28 days.

Comparison of Compressive Strength of Concrete using bottom ash and wood sawdust $5 \%(\mathrm{BA}+\mathrm{SK})$ vs 95\% AH, as shown in Figure 4.

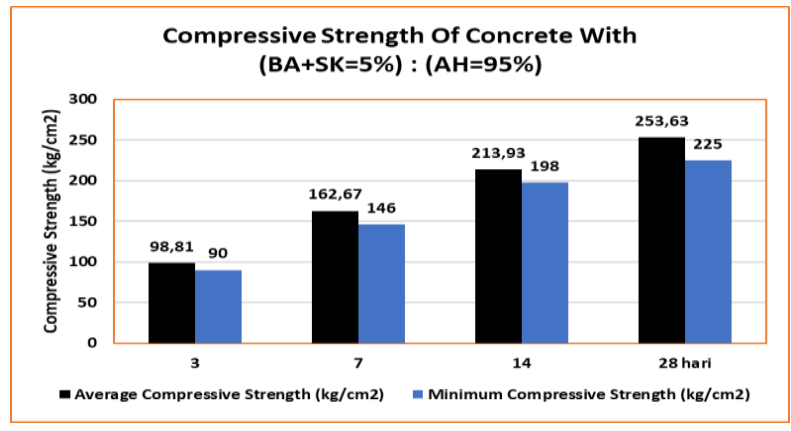

Figure 4 Comparison of Compressive Strength of Concrete at Age 3, 7, 14 and 28 days
From the results of testing the compressive strength of concrete, it is obtained that $253.63 \mathrm{~kg} / \mathrm{cm}^{2}$, has met the planned compressive strength of concrete, which is 225 $\mathrm{kg} / \mathrm{cm}^{2}$ at the age of 28 days.

Comparison of Compressive Strength of Concrete using bottom ash and sawdust 10\% (BA + SK) vs. $90 \%$ $\mathrm{AH}$, as shown in Figure 5.

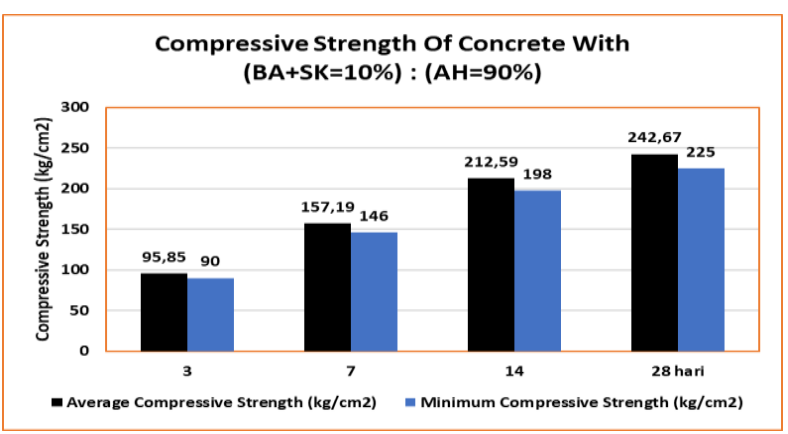

Figure 5 Comparison of Compressive Strength of Concrete at Age 3, 7, 14 and 28 days

From the test results, the compressive strength of the concrete is $242.67 \mathrm{~kg} / \mathrm{cm}^{2}$, it has met the planned compressive strength of $225 \mathrm{~kg} / \mathrm{cm}^{2}$ at the age of 28 days.

Comparison of Compressive Strength of Concrete using bottom ash and wood sawdust $15 \%(\mathrm{BA}+\mathrm{SK})$ vs. 85\% AH, as shown in Figure 6.

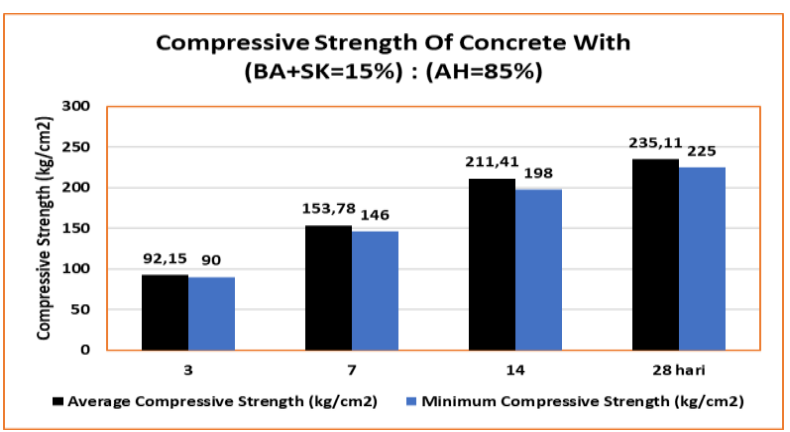

Figure 6 Comparison of Compressive Strength of Concrete at Age 3, 7, 14 and 28 days

From the test results, the compressive strength of concrete is $235.11 \mathrm{~kg} / \mathrm{cm}^{2}$, it has met the planned compressive strength of $225 \mathrm{~kg} / \mathrm{cm}^{2}$ at the age of 28 days.

Comparison of Compressive Strength of Concrete using bottom ash and wood sawdust $20 \%(\mathrm{BA}+\mathrm{SK}) \mathrm{vs}$. 80\% AH, as shown in Figure 7. 


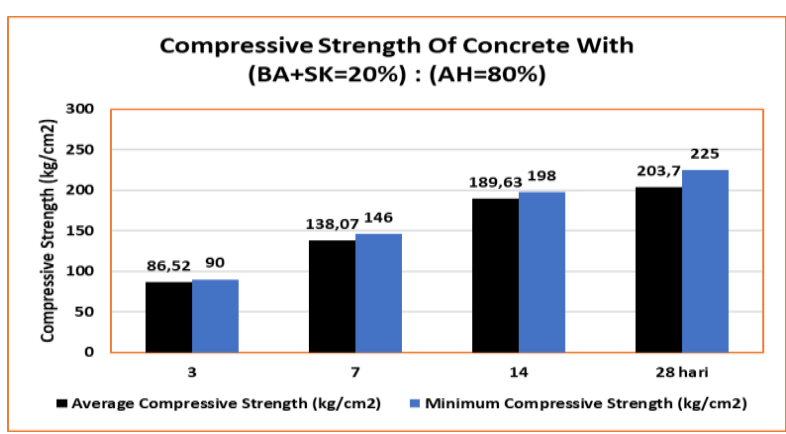

Figure 7 Comparison of Compressive Strength of Concrete at Age 3, 7, 14 and 28 days

From the test results, the compressive strength of $203.70 \mathrm{~kg} / \mathrm{cm}^{2}$ at the age of 28 days does not meet the planned compressive strength of the concrete, which is $225 \mathrm{~kg} / \mathrm{cm}^{2}$ at the age of 28 days.

Comparison of Compressive Strength of Concrete using bottom ash and wood sawdust $25 \%(\mathrm{BA}+\mathrm{SK})$ vs. $75 \% \mathrm{AH}$, as shown in Figure 8.

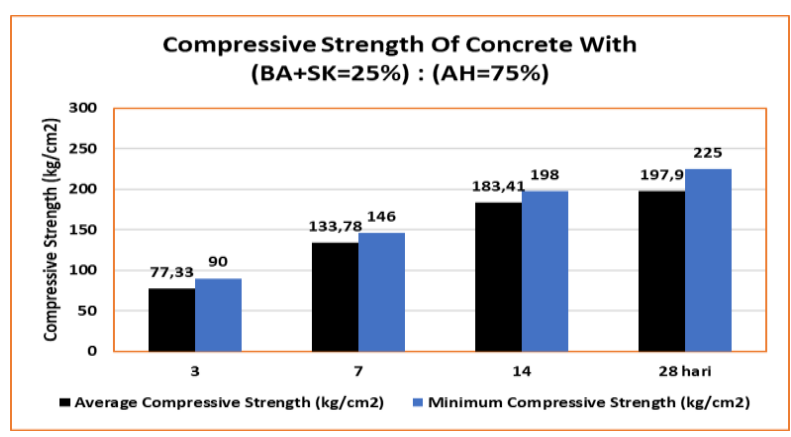

Figure 8 Comparison of Compressive Strength of Concrete at Age 3, 7, 14 and 28 days

From the test results, the compressive strength of $197.93 \mathrm{~kg} / \mathrm{cm}^{2}$ at the age of 28 days did not meet the planned compressive strength of the concrete, which was $225 \mathrm{~kg} / \mathrm{cm}^{2}$ at the age of 28 days.

\section{CONCLUSION}

Based on the test results, the compressive strength test of concrete without bottom ash and wood sawdust obtained a concrete compressive strength of 28 days which was $262.52 \mathrm{~kg} / \mathrm{cm}^{2}, 5 \%(\mathrm{BA}+\mathrm{SK})$ and $95 \% \mathrm{AH}$ obtained a compressive strength of $253.63 \mathrm{~kg} / \mathrm{cm}^{2}, 10 \%$ $(\mathrm{BA}+\mathrm{SK})$ and $90 \% \mathrm{AH}$ obtained a compressive strength of $242.67 \mathrm{~kg} / \mathrm{cm}^{2}, 15 \%$ (BA+SK) and $85 \% \mathrm{AH}$ obtained a compressive strength of $235.11 \mathrm{~kg} / \mathrm{cm}^{2}$. The results of the compressive strength test of the concrete above have met the planned compressive strength of the concrete, which is $225 \mathrm{~kg} / \mathrm{cm}^{2}$ at the age of 28 days. Comparison of the compressive strength of concrete with materials of $20 \%(\mathrm{BA}+\mathrm{SK})$ and $80 \% \mathrm{AH}$ obtained a compressive strength of $203.70 \mathrm{~kg} / \mathrm{cm} 2,25 \%(\mathrm{BA}+\mathrm{SK})$ and $75 \% \mathrm{AH}$ obtained a compressive strength of $197.93 \mathrm{~kg} / \mathrm{cm}^{2}$. The results of the compressive strength test of the concrete above do not meet the planned compressive strength of the concrete, which is $225 \mathrm{~kg} / \mathrm{cm}^{2}$ at the age of 28 days. It can be concluded that the more the use of bottom ash and sawdust into the concrete mixture, the lower the compressive strength of the concrete.

\section{AUTHORS' CONTRIBUTIONS}

The author would like to thank those who have provided financial support for the implementation of this activity, namely Sriwijaya State Polytechnic and Pt. Pilar Mas Perkasa who has given the opportunity to conduct this research.

\section{REFERENCES}

[1] American Society for Testing and Material (ASTM) 1980. Annual Book of ASTM Standards, Printed in Easton, Md. USA.

[2] American Association of State Highway and Transportation Official (AASHTO) 1998. Part I: Methods of Sampling and Testing, Washington, D.C.

[3] Antono, A. (1995). Bahan Konstruksi Teknik Sipil, Penerbit Universitas Atma Jaya, Jakarta.

[4] Alizar, (2010). "Bahan ajar teknologi bahan konstruksi jurusan teknik sipil

[5] Universitas Mercu Buana," Pusat pengembangan bahan ajar UMB, Jakarta.

[6] Halus dalam Pembuatan Beton.” Jurnal Fondasi, 4 (1).

[7] Departemen Pekerjaan Umum (1990). Metode Pengujian Kuat Tekan Beton, SK SNI

[8] 03-1974-1990, Bandung.

[9] Departemen Pekerjaan Umum (1990), Metode pembuatan dan perawatan benda uji

[10] beton di laboratorium, SK SNI 03-2493-1991, Bandung.

[11] Departemen Pekerjaan Umum (1992). Tata cara pembuatan rencana campuran

[12] untuk beton normal, SK SNI 03-2834-1992, Bandung.

[13] Jurnal SMARTek, Analisis Kuat Tekan Beton Ringan Tempurung Kelapa (I Wayan Suarnita dan Nicodemus Rupang) Vol. 7, No. 3, Agustus 2009.

[14] Kh, Sunggono, (1984). Buku Teknik Sipil, Penerbit NOVA, Bandung.

[15] Mulyono, Tri (2005). Teknologi Beton, Penerbit Andi Offset, Yogyakarta. 
[16] Murdock L.J, dan Brook K.M. (1999). Bahan dan Praktek Beton, Penerbit: Erlangga, Jakarta

[17] Prawito, Eri, (2010), “Analisa perbandingan berat jenis dan kuat tekan beton antara beton ringan dan beton normal dengan mutu beton K-200, Universitas Sumatera Utara, Medan.

[18] SNI M - 091989 - F Pengujian Berat Jenis dan Penyerapan Agregat Kasar.
[19] SNI M - 101989 - F Pengujian Berat Jenis dan Penyerapan Agregat Halus.

[20] SNI M - 021990 - F Pengujian Keausan Agregat Dengan Abrasi Los Angeles

[21] Tjokrodimulyo, Kardiyono (1992). Teknologi Beton, Penerbit Biro, Yogyakarta. 